\title{
Complex Behavior of Simple Repeats: The Fragile X Syndrome
}

\author{
BEN A. OOSTRA AND DICKY J. J. HALLEY \\ Department of Clinical Genetics, Erasmus University, 3000 DR Rotterdam, The Netherlands
}

\begin{abstract}
The fragile $X$ syndrome of mental retardation is one of the most common genetic diseases. The mutation causing this disease was the first of a new class of mutations involving repeat sequences disturbing gene function. Fragile $\mathrm{X}$ mutations consist of an expansion of a CGG trinucleotide repeat in the FMR1 gene, which is inactivated as a result of this expansion. The lack of FMR1 protein is believed to be responsible for the mental retardation. The mechanism and the timing of the repeat amplification are still not known. Characterization of the repeat has
\end{abstract}

clarified the genetics of fragile $\mathrm{X}$ syndrome, and has given tools to establish the diagnosis and to determine carrier status. (Pediatr Res 38: 629-637, 1995)
Abbreviations
SBMA, spinal and bulbar muscular atrophy DRPLA, dentatorubral and pallidoluysian atrophy PCR, polymerase chain reaction

The incidence of mental retardation is estimated to be $1-3 \%$ in the general population, ranging in severity from mild to profound (1). In most cases the (genetic) basis of this mental retardation is unknown. Among the known causes of mental retardation, fragile $X$ syndrome, affecting about 1:1,500 males and 1:2,500 females (2), accounts for $50 \%$ of the X-linked cases. Fragile $\mathrm{X}$ syndrome has been found in all ethnic groups studied. The identification of the gene involved and the advances in understanding the molecular basis of fragile $\mathrm{X}$ syndrome has clarified the unusual pattern of inheritance and has given tools for the identification of patients and carriers.

Fragile $\mathrm{X}$ syndrome is associated with a fragile site, designated FRAXA, on the long arm of the X chromosome at $\mathrm{Xq} 27.3$ in affected individuals. The characteristic microscopic gap in metaphase chromosomes can be induced by culturing cells under conditions that influence deoxynucleotide triphosphate levels (3). Over 100 different fragile sites have been described, dispersed over different chromosomes (4), of which only two are now associated with a disease phenotype: FRAXA and FRAXE which is located about $600 \mathrm{~kb}$ distal from FRAXA $(5,6)$. For a number of years confirmation of the clinical diagnosis of fragile $\mathrm{X}$ syndrome was carried out by cytogenetic detection of the fragile site in lymphocytes. Most affected males do express the fragile site in $2-50 \%$ of the cells. However, the site can be detected in only a proportion of obligate female carriers. Therefore, the cytogenetic test is not reliable in identifying carriers of the fragile $\mathrm{X}$ mutation. In addition two other fragile sites, FRAXE (5) and FRAXF (7),

Correspondence: Ben A. Oostra, Ph.D., Department of Clinical Genetics, Erasmus University, P.O. Box 1738, 3000 DR Rotterdam, The Netherlands. located close to FRAXA, may be diagnostically confused with FRAXA.

\section{CLINICAL ASPECTS}

In 1943 fragile X syndrome was described by Martin and Bell (8), who reported the first pedigree with clear familial mental retardation. The main characteristics of fragile $\mathrm{X}$ males are mental retardation, macroorchidism, large ears, prominent jaw and high-pitched, jocular speech (Fig. 1). A delayed development of speech and language is found but to a variable degree. There is a large variability in clinical expression of the syndrome, with mental retardation the most common feature. The mental retardation found in these males is varying between moderate and profound. Longitudinal observations indicate a deterioration of IQ with age; mental retardation may, for example, be moderate at age 12 and severe at age 25 . Hyperkinetic behavior and a problem with concentration are present in most affected males. Behavioral abnormalities also include hand flapping, hand biting, shyness, and avoidance of eye contact (9). A possible association between fragile X syndrome and autism has been suggested. However, the studies were small in size and Fisch (10) could not establish in a large pooled data set a statistically significant correlation between fragile $\mathrm{X}$ syndrome and autism. The more severely retarded males demonstrate a variety of autistic features (9). Also Reiss and Freund (11) found that $50-80 \%$ of a series of fragile $\mathrm{X}$ males meet partial criteria for autism although most did not show significant problems in reciprocal interactions with caregivers. Relatively little is known about structural abnormalities in the brain of fragile $X$ patients. It was shown that the volume 


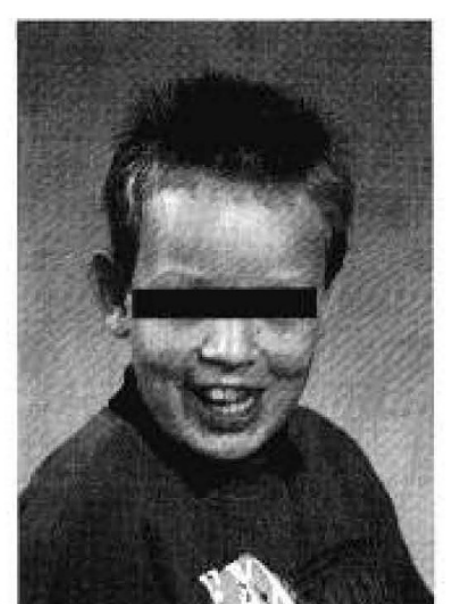

Figure 1. Mentally retarded boy with fragile X syndrome. Note long face with prominent forehead and ears.

of the hippocampus was enlarged compared with controls (12). On the other hand Reiss et al. $(13,14)$ showed that fragile $X$ males showed a significant decreased size of the posterior cerebellar vermis and increased size of the fourth ventricle, when compared with age- and sex-matched groups of fragile $X$ negative, developmentally disabled subjects and individuals with normal IQ.

In Table 1 physical features identified in fragile $\mathrm{X}$ males are listed. Macroorchidism is found in about $90 \%$ of all affected adult fragile $X$ males and usually develops after puberty (15). A long and narrow face is often less notable in prepuberal boys, but prominent ears are common in fragile $\mathrm{X}$ adults as well as children. Stigmata of connective tissue abnormalities are seen which include finger joint hypermobility and instability of other joints; flat feet were found in more then $50 \%$ of the patients.

Two subphenotypes of fragile $X$ syndrome have been described. The features of the Prader-Willi-like phenotype are extreme obesity with a full, round face, small, broad hands and feet, and regional skin hyperpigmentation (16). Fragile X patients with a Sotos-like phenotype show overgrowth in the first years of life, especially of the head (17). The cause of the phenotypic variation is unknown.

Table 1. Physical features of fragile $X$ males

\begin{tabular}{lc}
\hline \multicolumn{1}{c}{ Feature } & Patients with feature $(\%)$ \\
\hline Long ears & 66 \\
Prominent ears & 63 \\
High arched palate & 48 \\
Prominent jaw & 28 \\
Long face & 74 \\
Pectus excavatum & 43 \\
Hyperextensible fingers & 64 \\
Hand calluses & 45 \\
Double-jointed thumbs & 41 \\
Single palmar crease & 35 \\
Flat feet & 65 \\
Macro-orchidism & 74 \\
Scoliosis & 20 \\
Strabismus & 33 \\
\hline
\end{tabular}

Adapted from Hagerman (9).
Females with the fragile $\mathrm{X}$ syndrome show some degree of mental impairment, but are less severely affected than males (18). Females with fragile $\mathrm{X}$ syndrome may have behavioral and emotional problems (19). Typical facial characteristics and hypermobility of finger joints occurred in approximately $40 \%$ of adult females, but facial abnormalities were less common in children (20).

Transmission of the disease within affected families shows an unusual mode of inheritance. In fragile $X$ pedigrees males are predicted to carry the fragile $\mathrm{X}$ mutation but are phenotypically normal. These males (termed normal transmitting males) can transmit the mutation to their daughters, who are also unaffected, but grandsons of these males have a risk of exhibiting the full clinical phenotype (the mutation in affected individuals is called full mutation). The risk of having affected offspring to these daughters is $40 \%$, whereas the risk increases in the next generation to $50 \%$. Thus the likelihood of developing fragile $\mathrm{X}$ syndrome is dependent upon the position of the individual in the pedigree. This anticipation observed in fragile $\mathrm{X}$ families has become known as the Sherman paradox (21, 22). This paradox could be explained after the responsible gene and the gene defect were determined.

\section{FRAGILE X MENTAL RETARDATION GENE $F M R 1$}

In 1991 the gene involved in fragile X syndrome was cloned using a combination of positional cloning strategies (23). The FMRI gene was isolated from a cosmid that was covering the fragile site (24-26), and the gene consists of 17 exons spanning $38 \mathrm{~kb}$ (27). The gene with an mRNA of $4.8 \mathrm{~kb}$ is expressed in most tissues, although to a different extent with high expression in the tissues affected in fragile $\mathrm{X}$ syndrome, brain, and adult testes $(23,28,29)$. As a result of alternative splicing at the $3^{\prime}$ end of the gene, different mRNA species are made $(29,30)$ giving rise to many protein isoforms $(31,32)$. This may allow functional diversity, but no differences in expression patterns of the mRNA species between different tissues were found. Transgenic mice with a LacZ marker gene driven by the $F M R l$ promoter region of $2.5 \mathrm{~kb}$, which includes the CGG repeats, are crucial for determining the FMRI expression pattern (33).

The mouse homolog gene Fmrl was shown to be expressed in several areas of the brain and tubules of the testis in the adult mouse, whereas strong expression was observed in early mouse embryos (28). The highest level of FMRI expression in brain was observed in neurons, whereas glia cells contained very low levels. In adult testes, $F M R I$ protein was detected only in spermatogonia (32). The intracellular localization of the FMRI gene products was cytoplasmatic $(31,32)$. In the brain of 25 -week old fetuses, the gene was expressed in highest levels in cholinergic neurons of the nucleus basalis magnocellularis and in pyramidal neurons of the hippocampus (34). The early transcription of the gene and the distribution of mRNAs in human fetuses suggest that alterations of FMRI gene expression contributes to the pathogenesis of the fragile $\mathrm{X}$ syndrome and especially the mental retardation.

Although originally no strong homology with known genes was found in the predicted FMRI sequence, it was demon- 
strated that the protein product of the FMR1 gene contains sequence motifs characteristic of RNA-binding proteins: two $\mathrm{KH}$ domains and an RGG box $(35,36)$. It was shown that in vitro the FMR1 protein is binding to a subset of brain mRNA, including its own mRNA.

\section{BASIS OF THE FRAGILE X MUTATION}

The most interesting feature of the FMRI gene is a repeat motif, CGG, present in the first exon $(23,27)$. The start codon for translation is found 69 bases after the CGG repeat, indicating that the repeat is not translated into protein (29). The CGG repeat is polymorphic in normal individuals with allele sizes ranging from 6 to 54 repeats (37), with 30 repeats occurring most frequently (38). Within this normal range, the alleles are stably inherited. Within fragile $\mathrm{X}$ families two classes of unstable repeat numbers are observed. In normal male carriers and a proportion of female carriers, alleles sizes of between 43 and 200 copies are found which are termed premutation sized alleles, because they belong to individuals who carry the disease gene but show no phenotypic effects (37, 39). These premutation alleles are meiotically unstable, resulting in offspring with alleles with a repeat size different from the parental mutation. In clinically affected individuals alleles with repeat sizes above 200 repeats are found. Remarkably, the premutation expands to a full mutation only when transmitted by a female; consequently, daughters of normal transmitting males have only the premutation allele and never the full mutation and never show mental retardation or cytogenetic expression of the fragile site. The risk of expansion to the full mutation is correlated with the size of the premutation allele (37). If the repeat size is small (below 58 repeats), then the risk is of expansion to a full mutation, and thus having an affected child, is very low, and there are no such recorded instances. The risk for a premutation in the range of $59-65$ is relative small $(20-30 \%)$. If the repeat size is high ( $>90$ repeats) the risk is almost $100 \%$ to expand to a full mutation when transmitted. In that case the risk of having a affected child in the next generation due to the chance of inheriting the fragile $\mathrm{X}$ chromosome is $50 \%$. On average the risk for a premutation allele to expand to a full mutation is lower then $100 \%$, and this can explain the Sherman paradox which was described earlier.

In front of the FMRI gene a cluster of methylation-sensitive sites was detected $(40,41)$. These sites are normally unmethylated and are thought to represent the promoter of the FMRI gene. In fragile $X$ patients these sites are hypermethylated as well as the CGG repeat itself $(42,43)$. The expression of the FMRl gene was studied in lymphoblastoid cell lines and leukocytes from patients and controls $(44,45)$. FMRl mRNA was absent in most male fragile $\mathrm{X}$ patients, whereas normal individuals and carriers all showed expression. As a result $F M R l$ proteins are missing in cells of patients not expressing $F M R I$ mRNA $(31,32)$. As stated earlier the FMRl protein is binding to RNA and interacts with approximately $4 \%$ of human fetal brain message. The absence of the normal interaction of the FMRl protein with a subset of RNA molecules might result in the pleiotropic phenotype associated with the fragile $\mathrm{X}$ syndrome.
In a small number of fragile $\mathrm{X}$ syndrome patients who lack the repeat amplification, conventional mutations (point mutations and deletions) have been found in the FMR1 gene. These patients either lack the complete gene (46), part of the gene (47-49), or the FMRl promoter region (50). In a patient with the fragile $\mathrm{X}$ phenotype, a point mutation in the FMR1 gene has been described in one of the most highly conserved residues of the $\mathrm{KH}$ domain (51). The impairment of the RNA binding activity in this patient (52) gives strong evidence for an RNA-binding role of the FMRI protein. However, it is still unclear what role the FMRI protein is playing in the cell, especially in the neuron. These mutations support the hypothesis that fragile $\mathrm{X}$ syndrome is a single gene disorder and that loss of function of the FMRl gene is responsible for the clinical phenotype of the fragile $X$ syndrome.

There is strong evidence that the expanded region of CGG repeats is the fragile site itself. First, fluorescence in situ hybridization localized the fragile site in the proximity of the FMRl gene (26). Second, the fragile site can be seen only when the repeat size is above 200 repeats. Third, a positive correlation is found between repeat size and the level of cytogenetic expression (53). Fourth, a delayed replication of the repeat has been observed which might give rise to the configuration that can cause a break at the fragile site (54).

The CGG repeat in the FMRI gene is possibly a proteinbinding motif and has been shown to bind a not further characterized protein (55). This protein is unable to bind to full mutations as a result of methylation of the repeat sequence. How this lack of binding is affecting the phenotype is unknown.

\section{OTHER REPEAT DISEASES}

Finding heritable unstable triplet repeats at the fragile site led to the speculation that similar repeats might be found in other conditions showing unusual inheritance patterns (56). A number of genetic disorders involving triplet repeats have been found, although the exact repeat can be different: spinal and bulbar muscular atrophy (SBMA) (57); myotonic dystrophy (58-60); Huntington disease (61); spinocerebellar ataxia type 1 (62); FRAXE mental retardation (6); dentatorubral and pallidoluysian atrophy (DRPLA) (63); Haw River syndrome (64); Machado-Joseph disease (65). Furthermore, two fragile sites FRA16A and FRAXF, not associated with a disease phenotype, have been found to be caused by repeat amplifications $(66,67)$. All of these disorders except one affect neuronal cells as their primary target. In all trinucleotide repeat diseases, there is a threshold length for dynamic mutations of approximately 35 uninterrupted repeats. Amplification of the trinucleotide repeat above the threshold results in extreme instability. As all the repeats show the same threshold length of 35 uninterrupted repeats above which instability occurs, the expansion may be caused by a common mutation mechanism (68).

The four fragile sites are due to a large expansion of a CGG repeat of more than 200 repeats. The other triplet (CAG/CTG) repeat diseases are not associated with a fragile site, and therefore specific properties of the CGG repeat must be responsible for the induction of the fragile sites. In FRAXA and 
myotonic dystrophy the repeat is not translated into protein and is located in the $5^{\prime}$ - and $3^{\prime}$-untranslated part of the gene, respectively (Fig. 2). The expansions in these two disorders are very large, with increases of up to more then 2000 repeats. The largest group of repeat disease are six neurodegenerative conditions listed in group B (Fig. 2) and are caused by an amplified $\mathrm{CAG}$ repeat. The repeat expansions in these diseases are relatively small and never exceed 100 repeats. The repeat is translated into a polyglutamine stretch in the protein. Apart from this polyglutamine stretch there is no homology between these genes. Polyglutamine stretches have been found in DNAbinding proteins and expansion of such repeats may alter the biologic role of the protein involved $(69,70)$. These altered proteins most likely act in a manner consistent with a gain of function, as deletions in the gene causing SBMA do not cause SBMA (57).

The disorders involving trinucleotide repeats show genetic anticipation. Anticipation is the term given to the apparent occurrence of increasing severity of symptoms of an inherited disorder (through successive generations) with progressive earlier age of onset of the disease in successive generations. The anticipation seen in fragile $\mathrm{X}$ syndrome is an all or nothing phenomenon and does not fit the definition completely. For the other diseases an inverse correlation has been established between repeat length and age of onset.

\section{MECHANISM AND TIMING OF REPEAT AMPLIFICATION}

Because affected males rarely reproduce, a very high mutation rate has been suggested to maintain the frequency of the disease (71). However, there is no evidence for any recent mutations in fragile $X$ syndrome; all mothers of males with fragile $\mathrm{X}$ syndrome have been found to be carriers. Richards et al. (72) presented haplotype evidence for a founder effect in the fragile X mutation. Using microsatellite markers closely linked to FMR1, they showed linkage disequilibrium between the disease allele and certain alleles of these markers indicating that a small number of founder chromosomes are responsible for most of the fragile alleles. In studies of other populations it

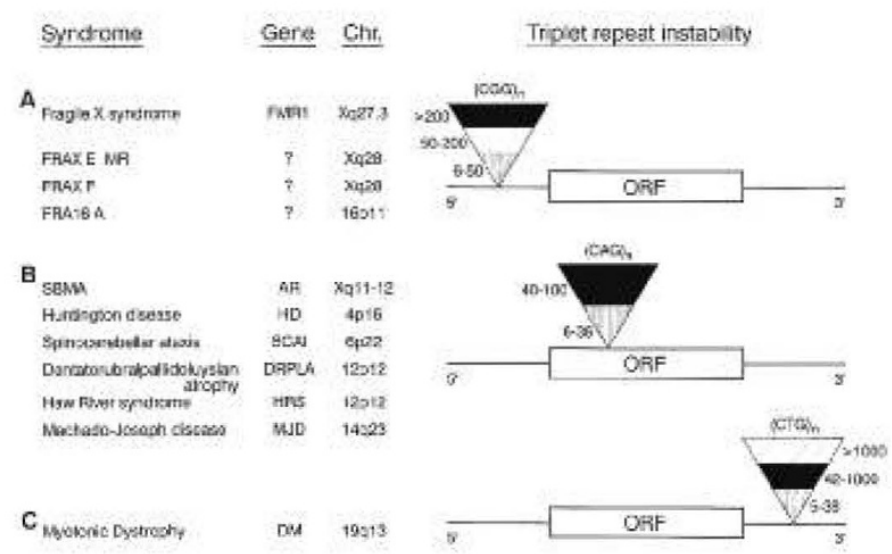

Figure 2. Genetic diseases associated with unstable repeats. Phenotypes with different repeat sizes: (area with vertical lines) normal; (white area) normal (premutation); (black area) affected; (areas with diagonal lines) affected (congenital form). was also found that allele distributions are different on fragile $\mathrm{X}$ chromosomes compared with normal $\mathrm{X}$ chromosomes, giving further support to the suggestion of a fragile $X$ founder effect (73-77). The data argue for a limited number of independent mutations that provided the origin of most of the present-day fragile $\mathrm{X}$ chromosomes and may explain the unexpected long history of some of these fragile $\mathrm{X}$ mutations (78, 79). It was proposed that it may take many generations, maybe up to 100 generations, before a mutation in a normal allele (most likely starting from chromosomes with repeat length in the upper normal range) results in a full mutation $(80,81)$.

In normal alleles the CGG repeat in the FMRI gene is interrupted by one or two AGG triplets leading to imperfect repeats $(82,83)$. These AGG repeats are found at the $5^{\prime}$ end of the repeat, whereas most of the length variation occurs at the $3^{\prime}$ end, and here the longest tracts of pure CGGs are found. In premutation alleles this stretch of pure CGGs is increased, and it is postulated that the threshold for instability is about 34 pure CGGs (84). As longer tracts of CGGs are found only at the $3^{\prime}$ end, there appears to be a polarity in the mechanism by which they arise, similar to the polarity in the occurrence of new mutations in several human minisatellites (85). The creation of a longer stretch of perfect repeats might be the result of a process of slippage of polymerization during the replication of the DNA leading to relatively small changes (86). They suggested that, depending on the length of the repeat, one single break is introduced during replication of the lagging strand. When this break is the end of an Okazaki fragment, slippage might occur. Another option might be that they have arisen by the loss of AGG triplets from longer interrupted arrays. If the perfect CGG repeat is exceeding the length of an Okazaki fragment ( \pm 150 bases) slippage at both sites of the repeat might occur leading to a rapid expansion to a full mutation (84, 86).

Daughters of affected males do not express the fragile $X$ syndrome at either the clinical or the cytogenetic level (87). These daughters do have a premutation despite the presence of a full mutation in their fathers. In a study of sperm in four male fragile X patients, Reyniers et al. (88) found that only the premutation was present, although the full mutation was present to the lymphocytes. The most simple model to explain the absence of extreme repeat expansion during paternal transmission is that the expression of the FMRI gene is a prerequisite for a proper germ cell proliferation in the testis and in the ovary $(88,89)$. High expression has been shown in male germ cells $(32,89,90)$. However, this hypothesis can be ruled out as a male has been described without FMRl protein due to a deletion of the FMRI gene promoter and this man has normal progeny (50). Also normal fertility of both male and female mice without a proper Fmrl gene indicates that Fmrl is not essential in reproduction (91). Another selection process could involve delayed replication of expanded repeats (54). A second model hypothesized that in the germ line cells a premutation is present and that amplification of the repeat does not occur in meiosis, but that the expansion occurs predominantly early in embryogenesis. This model can explain that the repeat expansion is not uniform: first is the different length of full mutation repeats found in blood cells, which is often shown as a large 
smear (Fig. 3); second mosaic patients carry the full mutation in some cells as well as a premutation or a deletion of the CGG repeat in some of the cells (92). However, the pattern of mosaicism was strictly identical in three pairs of monozygotic twins, indicating that the somatic heterogeneity and abnormal methylation are established early in development (93).

\section{ANIMAL MODEL}

The FMRl gene was shown to be conserved during evolution and is found in many animal species, even in species as divergent as yeast and Caenorhabditis elegans $(23,29)$. The region containing the CGG repeat has also been conserved in many species (94), which might point to an important regulatory role. There is marked sequence identity $(>97 \%$ at the amino acid level) between the murine homolog and the human gene, including the conservation of the CGG repeat (29). The ability to generate transgenic mice models by disruption of the murine Fmrl gene has offered the opportunity to get insight into the pathophysiology of human retardation (91). Like in fragile $\mathrm{X}$ patients these mice lack normal Fmrl RNA and protein. No gross pathologic abnormalities were observed in these mice, and the brain anatomy appears to be normal, but these mice have enlarged testes. Interestingly, these mice scored considerably different in behavior studies where they scored less well in spatial abilities and showed hyperactivity. An example of a behavior study is given in Fig. 4. In this test

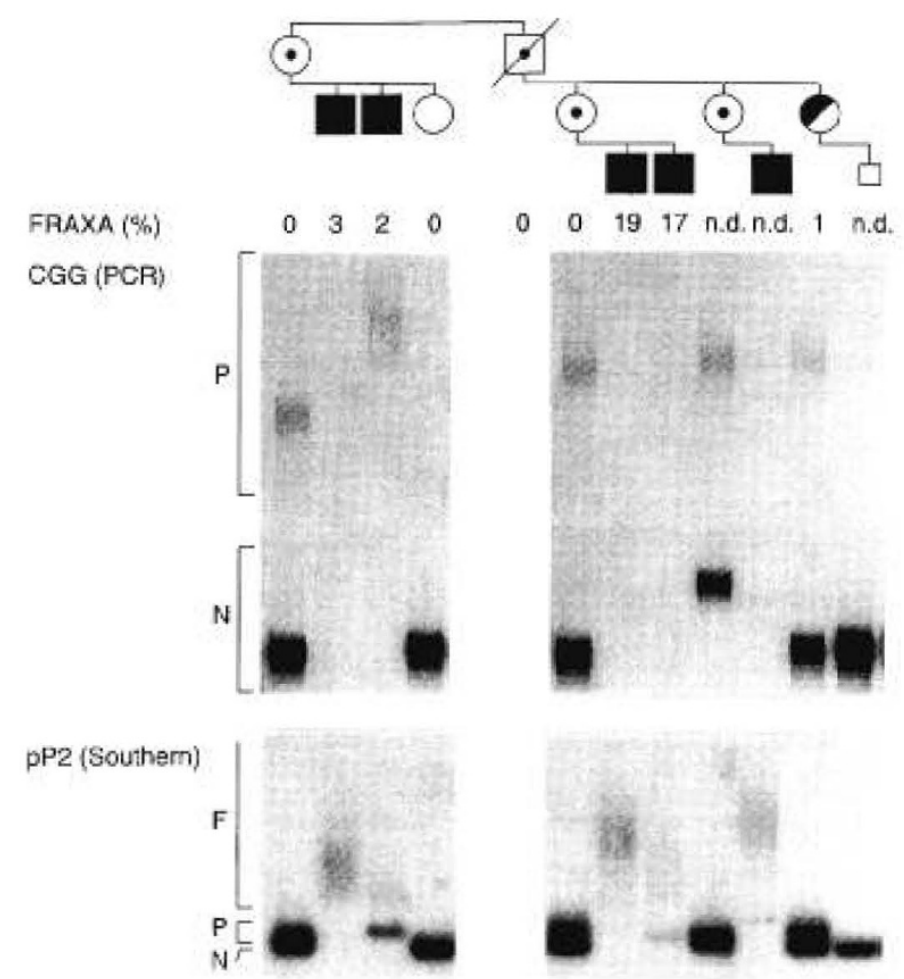

Figure 3. DNA diagnosis in a pedigree with fragile $\mathrm{X}$ syndrome. Filled square symbols represent affected males. Round symbols are for women. Dotted symbols for obligate carriers, half-filled for identified carriers, and empty for nonaffected, noncarriers. FRAXA $(\%)=$ percent expression of the fragile site FRAXA; $n . d=$ not determined. $N=$ normal fragment in CGG PCR analysis or Southern analysis with probe pP2; $P=$ premutation (PCR or Southern); $F=$ full mutation (Southern).
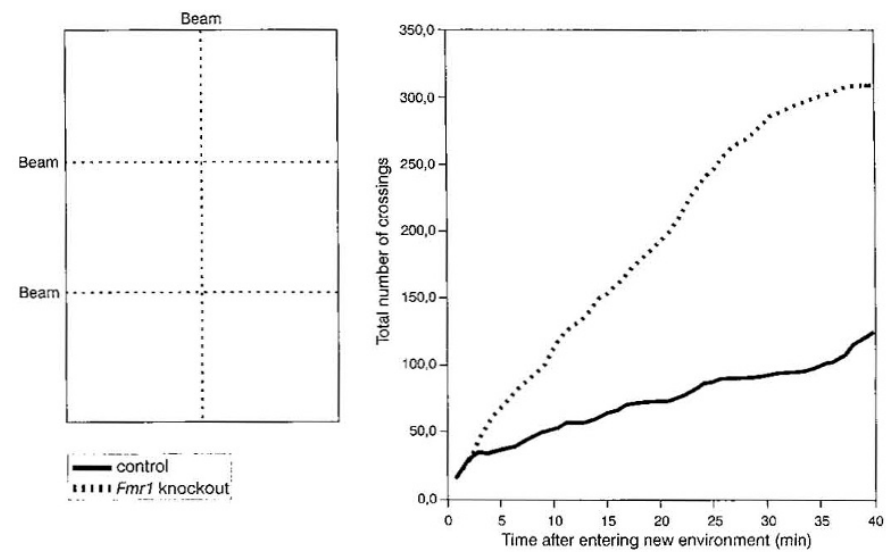

Figure 4. Motor activity test. (Left) Schematic drawing of the box used for the motor activity test. (Right) Results of the motor activity test.

the activity of the mutant mice was monitored by counting the number of crossings through infrared beams in an empty cage. Mutant mice showed significantly more crossings, which might indicate hyperactivity, and slower and less efficient learning of the environment. These mutant mice provide a good model in which to study the fragile $\mathrm{X}$ syndrome because these transgenic mice have physical, mental and behavioral abnormalities comparable to fragile $\mathrm{X}$ patients.

\section{PRACTICAL IMPLICATIONS FOR THE CLINICIAN}

Methods used in DNA diagnosis. The identification of the unstable CGG repeat in the FMRI gene prompted the application of DNA technology for the diagnosis of the fragile $\mathrm{X}$ syndrome. Detection of the full mutation in males and females can be routinely carried out by assessing the size of restriction enzyme generated DNA fragments encompassing the CGG repeat (95-100). As the full mutation $(F)$ is characterized by a size increase of the repeat with at least 200 CGG triplets, affected males show fragments exceeding the size of the normal fragment $(N)$ by at least $0.6 \mathrm{~kb}$ (Fig. 3). The DNA patterns of the affected males in the figure illustrate the common features and dissimilarities of full mutations in different individuals. Characteristically, each of the patterns has a diffuse aspect rather than presenting as a discrete band. This implies different degrees of repeat expansion in different cells and is a sign of the somatic instability of the expanded repeat. Some patients (see Fig. 3) show an additional, larger than normal, band well below the full mutation threshold. Phenotypic differences between these "mosaic" patients and "full mutation only" patients have not been noted $(53,101)$.

The full mutation is not only defined by size but also by methylation, which may sometimes act as an independent determinant of the phenotype. Some mild cases without mental impairment have been described with mutations of borderline size or even fully expanded mutations in the absence of (complete) methylation $(100,102,103)$. A test for the methylation status can be easily combined with Southern analysis by including a digestion with a methylation sensitive restriction enzyme.

The patterns observed in females are necessarily more complex due to the presence of the normal $\mathrm{X}$ chromosome. The 
pedigree (Fig. 3) shows several carriers of the premutation with affected offspring. The figure illustrates the limits of the method as some of the premutations are barely resolved from the normal X chromosome derived band. An alternative technique is PCR amplification of the CGG repeat $(37,38)$. The example in Fig. 3 represents an application of PCR in the presence of radioactively labeled nucleotides, and subsequent size separation and direct autoradiography. The figure illustrates the complementary sensitivities of the methods with excellent resolution of premutations after PCR, but with the detection of full mutations restricted to the more laborious Southern blotting method. Although adaptations of the PCR method have been described that do detect the full mutation (38), most laboratories involved in the diagnosis of fragile $\mathrm{X}$ syndrome patients and the detection of carriers use a combination of a PCR-based method and Southern blotting. Of the rarely occurring other mutations in the FMRI gene, deletions will also be detected using these methods (46-50). Only a point mutation, which has been observed once (51), will go unnoticed.

Applications. Obviously, analysis of the FMRI gene in families with an established case of fragile $\mathrm{X}$ syndrome is a prominent application of DNA diagnosis. Female relatives of patients are at increased risk of being a carrier. Whereas cytogenetic analysis of the fragile site at Xq27.3 was known to detect only about $50 \%$ of female carriers, DNA analysis reliably discriminates between female carriers and noncarriers (Fig. 3).

The occurrence of pedigrees with fragile $\mathrm{X}$ syndrome in different branches, which were connected through "normal transmitting males" (see Fig. 3, first generation), has remained unexplained until the identification of the stepwise CGG repeat expansion in the FMRI gene. To date, normal transmitting males are known to inevitably transmit a premutation to all their daughters. Hence, the identification of a male carrier may have widespread consequences, because it may implicitly identify female carriers, who are at risk of having affected children.

Females known to be carriers can be offered the possibility of prenatal DNA diagnosis. Prenatal DNA analysis can be routinely carried out using a chorionic villus sample, as well as after amniocentesis $(38,97,104,105)$. The obvious advantage of chorion villi is the early stage of pregnancy. On the other hand methylation tests can be reliably performed on DNA from amniotic fluid cells, which is not possible on chorion villi DNA (97). The accuracy of the first trimester DNA assay has been shown to be greater than the formerly applied cytogenetic method (97).

Males with the full mutation are considered to be invariably affected; the situation is more complicated in the case of a female with a full mutation. It has been known for a long time that a proportion of female carriers are mentally retarded. Knowledge on the repeat expansion has clarified this issue to some degree, as we know now that premutations are not associated with mental impairment (96). The majority of females (about 60\%) carrying the full mutation, however, may be mentally retarded, but to a lesser degree than males with the full mutation (101). Consequently, the decision whether or not to terminate a pregnancy of a female fetus with a full mutation may be very difficult and requires delicate counseling.

Fig. 3 (last lane) shows an example of first trimester DNA diagnosis. The mother was identified as a carrier of the premutation, and she requested prenatal diagnosis. A normal pattern was obtained with Southern analysis of chorion villusderived DNA of the male fetus. CGG PCR analysis confirmed the diagnosis of an unaffected male by the detection of a single band corresponding in size to the normal maternal allele.

Inasmuch as fragile $\mathrm{X}$ syndrome is the most frequent cause of inherited mental retardation, its diagnosis is often considered during diagnostic work up of patients with an otherwise unexplained clinical picture. A study of 525 routine referrals by a genetics center resulted in the identification of $12(3 \%)$ fragile X syndrome patients (106). Recently, we surveyed a group of patients, who were referred by pediatricians, (child) neurologists, and clinical geneticists, and the range of symptoms of the fragile $\mathrm{X}$ syndrome was not consistently assessed. Ten unrelated patients (4\%) with fragile $\mathrm{X}$ syndrome were identified (107). In these and other (101) studies patients were noted with a full mutation in the absence of expression of the fragile site FRAXA. Apparently, direct detection of the repeat expansion is more sensitive than the cytogenetic method. On the other hand, patients with abnormal karyotypes of a different nature were detected at the same frequency as fragile $X$ patients, which argues strongly in favor of a combination of cytogenetic and DNA diagnosis in cases of unexplained mental retardation $(106,107)$.

As was stated earlier, the phenotype of fragile $\mathrm{X}$ syndrome is variable, with distinct subtypes, which differ from the Martin Bell phenotype, but which show phenotypic overlap with either Prader-Willi syndrome or Sotos syndrome $(16,17)$. In fact, one of the fragile $\mathrm{X}$ patients identified in our diagnostic study had previously been thought to be affected with Prader-Willi syndrome. Therefore, patients referred for DNA diagnosis of Prader-Willi syndrome, who appear to be negative for the characteristic chromosome 15-related abnormalities, are now routinely tested for fragile $\mathrm{X}$ syndrome in our laboratory, as are patients with a Sotos syndrome phenotype.
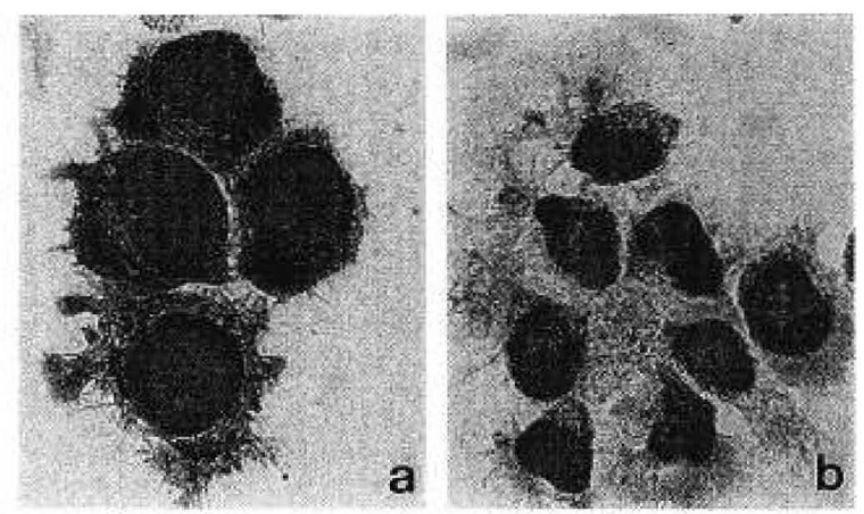

Figure 5. Antibody test for expression of FMRl protein in blood smears of control $(a)$ and fragile $\mathrm{X}$ patient $(b)$. For details of experiment, see Willemsen et al. (117). 


\section{FUTURE DIAGNOSTIC PROSPECTS}

There are two prominent reasons, which could favor a wider application of diagnosis of the fragile $\mathrm{X}$ syndrome. First, a correct (early) diagnosis provides better opportunities for the patient to receive adequate support $(9,108)$. Second, finding previously unidentified individuals with the syndrome enables couples at risk of having an affected child to make an informed reproductive choice (109). In New South Wales, Australia, a screening program among intellectually handicapped individuals to detect fragile $\mathrm{X}$ syndrome cytogenetically has been operating since 1984. In the (selected) cases where testing was offered, a 79\% uptake of the service was reported (109). A similar positive response rate (87\%) among parents of children with special education needs in Wessex, UK (110), illustrates the acceptance by the families of testing in high risk populations. The numbers of fragile $\mathrm{X}$ patients identified show a strong correlation with the screening criteria. Turner et al. (109) reported $6-10.4 \%$ fragile $X$ patients among the tested population, depending on the stringency of the criteria, whereas Hagerman et al. (111) used broad criteria and detected $1.1 \%$ affected individuals among special education school children. The study by Hagerman et al. comprised 439 individuals and was carried out by DNA testing using saliva, which shows the feasibility of this noninvasive protocol in a screening sample of this size.

A much broader target for screening programs would be the general population. Palomaki and Haddow (112) suggested a population-based screening for carriers during pregnancy and the subsequent option of prenatal diagnosis for those identified with a premutation or a full mutation. One of the main arguments against programs aimed at the identification of carriers is the lack of a clear distinction between large normal alleles and small premutations. Premutations observed in fragile $\mathrm{X}$ families are characterized both by increased size and meiotic instability (37). Based on the frequency of the disease, premutations have been estimated earlier to occur on 1:500-1:800 chromosomes in the general population $(21,22)$. Estimations of the actual allele frequency of PCR-detectable premutations in the general population have been 1:125 (113) and 1:510 (114), but they are necessarily inaccurate due to limited possibilities to study (in)stability upon transfer to the next generation. Because the frequency of stable premutation-sized alleles may be four times higher than the frequency of true premutations (114), carrier screening programs would generate high numbers of false positives.

A different approach has been proposed by Young (115), who suggested to restrict population screening to a search for full mutations in newborn males. The advantages mentioned are the possibility of an accurate prognosis and the offer of testing the extended family. Experience with screening newborns for Duchenne's muscular dystrophy has been reported by Bradley et al. (116), whose pilot study in Wales, UK, has been well received. If screening newborn males for fragile $\mathrm{X}$ syndrome were to be considered, new diagnostic assays have to be developed, as the presently used DNA technology is far too complicated and time consuming for the processing of large numbers of samples.
An alternative assay would be to test the gene product instead of the gene. As described above, the full mutation is accompanied by silencing of the gene and, consequently, absence of the protein product FMRP. Recently, an antibody test has been developed, which reliably discriminates between affected and normal males using blood smears of 1-2 drops (117). An example of this test is shown in Fig. 5. This rapid and inexpensive test would be suitable for the screening of large numbers of males. Hence, considerations on screening programs may soon be focused on issues of social acceptance and the availability of adequate counseling facilities rather than technical limitations.

Acknowledgments. The authors thank Drs. A. LantiguaCruz, L. Heredero, and L. B. A. De Vries for referring the fragile $\mathrm{X}$ families and $\mathrm{M}$. Willemsen for the photograph of the antibody test. We thank Drs. H. Galjaard and M. F. Niermeijer for their continuous support during our fragile $\mathrm{X}$ research.

\section{REFERENCES}

1. Szymanski LS, Crocker AC 1989 Mental retardation. In: Kaplan HI, Sadock, B (ed) Comprehensive Textbook of Psychiatry, 5th Ed. Williams \& Wilkins, Baltimore, pp 1728-1771

2. Webb TP, Bundey SE, Thake AI, Todd J 1986 Population incidence and segregation ratios in the Martin-Bell syndrome. Am J Med Genet 23:573-580

3. Sutherland GR 1977 Fragile sites on human chromosomes: demonstration of their dependence on the type of tissue culture medium. Science 197:265-266

4. Sutherland GR, Ledbetter DH 1989 Report of the committee on cytogenetic markers. Cytogenet Cell Genet 51:452

5. Sutherland GR, Baker E 1992 Characterisation of a new rare fragile site easily confused with the fragile X. Hum Mol Genet 1:111-113

6. Knight SJ, Flannery AV, Hirst MC, Campbell L, Christadoulou Z, Phelps SR, Pointon J, Middleton-Price HR, Barnicoat A, Pembrey ME, Holland J, Oostra BA, Bobrow M, Davies KE 1993 Trinucleotide repeat amplification and hypermethylation of a CpG island in FRAXE mental retardation. Cell 74:127-134

7. Hirst MC, Barnicoat A, Flynn G, Wang Q, Daker M, Buckle VJ, Davies KE, Bobrow M 1993 The identification of a third fragile site, FRAXF, in Xq27-q28 distal to both FRAXA and FRAXE. Hum Mol Genet 2:197-200

8. Martin JP, Bell J 1943 A pedigree of mental defect showing sex-linkage. J Neurol Psychiatry 6:154-157

9. Hagerman RJ 1991 Physical and behavioral phenotype. In: Hagerman RJ, Silverman AC (eds) Fragile X Syndrome: Diagnosis, Treatment and Research. Johns Hopkins University Press, Baltimore, pp 1-68

10. Fisch GS 1992 Is autism associated with the fragile X syndrome? Am J Med Genet 43:78-86

11. Reiss AL, Freund LS 1990 Fragile X syndrome, DSM-III-R, and autism. J Am Acad Child Psychiatry 29:885-891

12. Reiss AL, Lee J, Freund L 1994 Neuroanatomy of fragile X syndrome: the temporal lobe. Neurology 44:1317-1324

13. Reiss AL, Aylwarth E, Freund LS, Joshi PK, Bryan RN 1991 Neuroanatomy of fragile X syndrome: the posterior fossa. Ann Neurol 29:26-32

14. Reiss AL, Freund L, Tseng JE, Joshi PK 1991 Neuroanatomy in fragile X females: the posterior fossa. Am J Hum Genet 49:279-288

15. Butler MG, Brunswig A, Miller LK, Hagerman RJ 1992 Standards for selected anthropogenetic measurements in males with fragile $\mathrm{X}$ syndrome. Pediatrics 89:1059-1062

16. De Vries BB, Fryns JP, Butler MG, Canziani F, Wesby-van-Swaay E, van-Hemel JO, Oostra BA, Halley DJ, Niermeijer MF 1993 Clinical and molecular studies in fragile X patients with a Prader-Willi-like phenotype. J Med Genet 30:761-766

17. Beemer FA, Veenema H, Pater JM 1986 Cerebral gigantism (Sotos syndrome) in two patients with $\mathrm{Fra}(\mathrm{X})$ chromosome. Am J Med Genet 23:221-226

18. Mazzocco MMM, Hagerman RJ, Pennington BF 1992 Problem solving limitations among cytogenetically expressing fragile X woman. Am J Med Genet 43:78-86

19. Lachiewicz AM 1992 Abnormal behaviors of young girls with fragile X syndrome. Am J Med Genet 43:72-77

20. Loesch DZ, Hay DA 1988 Clinical features and reproductive patterns in fragile X female heterozygotes. J Med Genet 25:407-414

21. Sherman SL, Morton NE, Jacobs PE, Turner G 1984 The marker (X) chromosome: a cytogenetic and genetic analysis. Ann Hum Genet 48:21-37

22. Sherman SL, Jacobs PA, Morton NE, Froster-Iskenius U, Howard-Peebles PN, Nielsen KB, Partington NW, Sutherland GR, Turner G, Watson M 1985 Further segregation of the fragile $\mathrm{X}$ syndrome with special reference to transmitting males. Hum Genet 69:289-299

23. Verkerk AJ, Pieretti M, Sutcliffe JS, Fu YH, Kuhl DP, Pizzuti A, Reiner O, Richards $S$, Victoria MF, Zhang FP, Eussen BE, Van Ommen GJB, Blonden LAJ, Riggins GJ, Chastain JL, Kunst CB, Galjaard H, Caskey CT, Nelson DL, Oostra BA, Warren ST 
1991 Identification of a gene (FMR-1) containing a CGG repeat coincident with a breakpoint cluster region exhibiting length variation in fragile $\mathrm{X}$ syndrome. Cell 65:905-914

24. Heitz D, Rousseau F, Devys D, Saccone S, Abderrahim H, Le Paslier D, Cohen D, Vincent A, Toniolo D, Della Valle G, Johnson S, Schlessinger D, Oberle I, Mandel JL 1991 Isolation of sequences that span the fragile $\mathrm{X}$ and identification of a fragile X-related CpG island. Science 251:1236-1239

25. Hirst MC, Rack K, Nakahori Y, Roche A, Bell MV, Flynn G, Christadoulou Z, MacKinnon RN, Francis M, Littler AJ, Anand R, Poustka AM, Lehrach H, Schlessinger D, D’Urso M, Buckle VJ, Davies KE 1991 A YAC contig across the fragile X site defines the region of fragility. Nucleic Acids Res 19:3283-3288

26. Verkerk AJ, Eussen BH, Van Hemel JO, Oostra BA 1992 Limited size of the fragile X site shown by fluorescence in situ hybridization. Am J Med Genet 43:187-191

27. Eichler EE, Richards S, Gibbs RA, Nelson DL 1993 Fine structure of the human FMR1 gene. Hum Mol Genet 2:1147-1153

28. Hinds HL, Ashley CT, Sutcliffe JS, Nelson DL, Warren ST, Housman DE, Schalling M 1993 Tissue specific expression of FMR-1 provides evidence for a functional role in fragile X syndrome. Nat Genet 3:36-43

29. Ashley CT, Sutcliffe JS, Kunst CB, Leiner HA, Eichler EE, Nelson DL, Warren ST 1993 Human and murine FMR-1: alternative splicing and translational initiation downstream of the CGG-repeat. Nat Genet 4:244-251

30. Verkerk AJ, De Graaff E, De Boulle K, Eichler EE, Konecki DS, Reyniers E, Manca A, Poustka A, Willems PJ, Nelson DL, Oostra BA 1993 Alternative splicing in the fragile X gene FMRI. Hum Mol Genet 2:399--404

31. Verheij C, Bakker CE, de-Graaff E, Keulemans J, Willemsen R, Verkerk AJ, Galjaard H, Reuser AJ, Hoogeveen AT, Oostra BA 1993 Characterization and localization of the FMR-1 gene product associated with fragile X syndrome. Nature 363:722-724

32. Devys D, Lutz Y, Rouyer N, Bellocq JP, Mandel JL 1993 The FMR-1 protein is cytoplasmic, most abundant in neurons and appears normal in carriers of a fragile $\mathrm{X}$ premutation. Nat Genet 4:335-340

33. Hergersberg M, Matsuo K, Gassman M, Schaffner W, Luscher B, Rulicke T, Aguzzi A 1995 Tissue-specific expression of a FMR1/b-galactosidase fusion gene in transgenic mice. Hum Mol Genet 4:359-366

34. Abitbol M, Menini C, Delezoide AL, Rhyner T, Vekemans M, Mallet J 1993 Nucleus basalis magnocellularis and hippocampus are the major sites of FMR-1 expression in the human fetal brain. Nat Genet 4:147-153

35. Siomi H, Siomi MC, Nussbaum RL, Dreyfuss G 1993 The protein product of the fragile X gene, FMR1, has characteristics of an RNA-binding protein. Cell 74:291298

36. Ashley C Jr, Wilkinson KD, Reines D, Warren ST 1993 FMR1 protein: conserved RNP family domains and selective RNA binding. Science 262:563-568

37. Fu YH, Kuhl DP, Pizzuti A, Pieretti M, Sutcliffe JS, Richards S, Verkerk AJ, Holden JJ, Fenwick R Jr, Warren ST, Oostra BA, Nelson DL, Caskey CT 1991 Variation of the CGG repeat at the fragile X site results in genetic instability: resolution of the Sherman paradox. Cell 67:1047-1058

38. Brown WT, Houck GE, Jeziorowska A, Levinson FN, Ding X, Dobkin C, Zhong N, Henderson J, Brooks SS, Jenkins EC 1993 Rapid fragile-X carrier screening and prenatal diagnosis using a nonradioactive PCR test. JAMA 270:1569-1575

39. Kremer EJ, Pritchard M, Lynch M, Yu S, Holman K, Baker E, Warren ST, Schlessinger D, Sutherland GR, Richards RI 1991 Mapping of DNA instability at the fragile $X$ to a trinucleotide repeat sequence $p(C C G) n$. Science 252:1711-1714

40. Bell MV, Hirst MC, Nakahori Y, MacKinnon RN, Roche A, Flint TJ, Jacobs PA, Tommerup N, Tranebjaerg L, Froster-Iskenius U, Kerr B, Turner G, Lindebaum D, Winter R, Pembrey M. Thibodeau S, Davies KE 1991 Physical mapping across the fragile $\mathrm{X}$ : hypermethylation and clinical expression of the fragile $\mathrm{X}$ syndrome. Cell 64:861-866

41. Vincent A, Heitz D, Petit C, Kretz C, Oberlé I, Mandel JL 1991 Abnormal pattern detected in fragile-X patients by pulsed-field gel electrophoresis. Nature 349:624 626

42. Hansen RS, Gartler SM, Scott CR, Chen SH, Laird CD 1992 Methylation analysis of CGG sites in the CpG island of the human FMR1 gene. Hum Mol Genet 1:571-578

43. Hornstra IK, Nelson DL, Warren ST, Yang TP 1993 High resolution methylation analysis of the FMR1 gene trinucleotide repeat region in fragile $\mathrm{X}$ syndrome. Hum Mol Genet 2:1659-1665

44. Pieretti M, Zhang FP, Fu YH, Warren ST, Oostra BA, Caskey CT, Nelson DL 1991 Absence of expression of the FMR-1 gene in fragile X syndrome. Cell 66:817-822

45. Sutcliffe JS, Nelson DL, Zhang F, Pieretti M, Caskey CT, Saxe D, Warren ST 1992 DNA methylation represses FMR-1 transcription in fragile X syndrome. Hum Mol Genet 1:397-400

46. Gedeon AK, Baker E, Robinson H, Partington MW, Gross B, Manca A, Korn B, Poustka A, Yu S, Sutherland GR, Mulley JC 1992 Fragile X syndrome without CCG amplification has an FMR1 deletion. Nat Genet 1:341-344

47. Wöhrle D, Kotzot D, Hirst MC, Manca A, Korn B, Schmidt A, Barbi G, Rott HD, Poustka A, Davies KE, Steinbach P 1992 A microdeletion of less than $250 \mathrm{~kb}$ including the proximal part of the FMR-I gene and the fragile-X site, in a male with the clinical phenotype of fragile-X syndrome. Am J Hum Genet 51:299-306

48. Tarleton J, Richie R, Schwartz C, Rao K, Aylsworth AS, Lachiewicz A 1993 An extensive de novo deletion removing FMR1 in a patient with mental retardation and the fragile X syndrome phenotype. Hum Mol Genet 2:1973-1974

49. Gu YH, Lugenbeel KA, Vockley JG, Grody WW, Nelson DL 1994 A de novo deletion in FMR1 in a patient with developmental delay. Hum Mol Genet 3:17051706

50. Meijer H, De Graaff E, Merckx D, Jongbloed R, De Die-Smulders C, Engelen J, Fryns JP, Curfs P, Oostra BA 1994 A deletion of 1:6 kb proximal to the CGG repeat of the FMR1 gene causes the clinical phenotype of the Fragile X syndrome. Hum Mol Genet 3:615-620

51. De Boulle K, Verkerk AJ, Reyniers E, Vits L, Hendrickx J, Van Roy B, Van den Bos F, de Graaff E, Oostra BA, Willems PJ 1993 A point mutation in the FMR-1 gene associated with fragile X mental retardation. Nat Genet 3:31-35

52. Siomi H, Choi M, Siomi MC, Nussbaum RL, Dreyfuss G 1994 Essential role for KH domains in RNA binding: impaired RNA binding by a mutation in the $\mathrm{KH}$ domain of FMR1 that causes fragile X syndrome. Cell 77:33-39

53. De Vries BBA, Wiegers AM, De Graaff E, Verkerk AJMH, Van Hemel JO, Halley DJJ, Fryns JP, Curfs LMG, Niermeijer MF, Oostra BA 1993 Mental status and fragile X expression in relation to FMR-1 gene mutation. Eur J Hum Genet 1:72-79

54. Hansen RS, Canfield TK, Lamb MM, Gartler SM, Laird CD 1993 Association of fragile X syndrome with delayed replication of the FMR1 gene. Cell 73:1403-1409

55. Richards RI, Holman K, Yu S, Sutherland GR 1993 Fragile X syndrome unstable element, $p(C C G) n$, and other simple tandem repeat sequences are binding sites for specific nuclear proteins. Hum Mol Genet 2:1429-1435

56. Sutherland GR, Haan EA, Kremer E, Lynch M, Pritchard M, Yu S, Richards RI 1991 Hereditary unstable DNA: a new explanation for some old genetic questions? Lancet 338:289-292

57. La Spada AR, Wilson EM, Lubahn DB, Harding AE, Fischbeck KH 1991 Androgen receptor gene mutations in X-linked spinal and bulbar muscular atrophy. Nature 352:77-79

58. Brook JD, McCurrach ME, Harley HG, Buckler AJ, Church D, Aburatani H, Hunter K, Stanton VP, Thirion JP, Hudson T, Sohn R, Zemelman B, Snell RG, Rundle SA Crow S, Davies J, Shelbourne P, Buxton J, Jones C, Juvonen V, Johson K, Harper PS, Shaw DJ, Housman DE 1992 Molecular basis of myotonic dystrophy: expansion of a trinucleotide (CTG) repeat at the $3^{\prime}$ end of a transcript encoding a protein kinase family member. Cell 68:799-808

59. Fu YH, Pizzuti A, Fenwick RJ, King J, Rajnarayan S, Dunne PW, Dubel J, Nasser GA, Ashizawa T, de Jond P, Wieringa B, Korneluk R, Perryman MB, Epstein HF, T. CC 1992 An unstable triplet repeat in a gene related to myotonic muscular dystrophy. Science 255:1256-1258

60. Mahadevan M, Tsilfidis C, Saborin L, Shutler G, Amemiya C, Jansen G, Neville C, Narang M, Barcelo J, O'Hoy K, Leblond S, Earle-Macdonald J, de Jong P, Wieringa B, Korneluk RG 1992 Myotoniv dystrophy mutation: an unstable CTG repeat in the $3^{\prime}$ untranslated region of the gene. Science 255:1253-1255

61. The Huntington's Disease Collaborative Research Group 1993 A novel gene containing a trinucleotide repeat that is expanded and unstable on Huntington's disease chromosomes. Cell 72:971-983

62. Orr HT, Chung M, Banfi S, Kwiatkowski TJ, Servadio A, Beaudet A, McCall AE, Duvick LA, Ranum LPW, Zohgbi HY 1993 Expansion of an unstable trinucleotide CAG repeat in spinocerebellar ataxia type 1 . Nat Genet 4:221-226

63. Koide R, Ikeuchi T, Onodera O, Tanaka H, Igarashi S, Endo K, Takahashi H, Kondo R, Ishikawa A, Hayashi T, Saito M, Tomoda A, Miike T, Naito H, Ikuta F, Tsuji S 1994 Unstable expansion of CAG repeat in hereditary dentatorubral-pallidoluysian atrophy (DRPLA). Nat Genet 6:9-13

64. Burke JR, Wingfield MS, Lewis KE, Roses AD, Lee JE, Hulette C, Pericak-Vance MA, Vance JM 1994 The Haw River syndrome: dentatorubropallidoluysian atrophy (DRPLA) in an African-American family. Nat Genet 7:521-524

65. Kawaguchi Y, Okamoto T, Taniwaki M, Aizawa M, Inoue M, Katayama S, Kawakami H, Nakamura S, Nishimura M, Akiguchi I, Kimura J, Narumiya S, Kakizuka A 1994 CAG expansions in a novel gene for Machado-Joseph disease at chromosome 14q32.1. Nat Genet 8:221-228

66. Nancarrow JK, Kremer E, Holamn K, Eyre H, Doggett NA, Le Paslier D, Callen DF, Sutherland GR, Richards RI 1994 Implications of FRA16A structure for the mechanism of chromosomal fragile site genesis. Science 264:1938-1941

67. Parrish JE, Oostra BA, Verkerk AJHM, Richards CS, Spikes AS, Shaffer LG, Nelson DL 1994 Isolation of a GCC repeat showing expansion in FRAXF, a fragile site distal to FRAXA and FRAXE. Nat Genet 8:229-235

68. Richards RI, Sutherland GR 1992 Dynamic mutations: a new class of mutations causing human disease. Cell 70:709-712

69. Gerber HP, Seipel K, Georgiev O, Hoffere M, Hug M, Rusconi S, Schaffner W 1994 Transcriptional activation modulated by homopolymeric glutamine and proline stretches. Science 263:808-811

70. Chamberlain NL, Criver ED, Miesfeld RL 1994 The length and location of CAG trinucleotide repeats in the androgen receptor $\mathrm{N}$-terminal domain affect transactivation function. Nucleic Acids Res 22:3181-3186

71. Brown WT 1990 The fragile X: progress toward solving the puzzle. Am J Hum Genet 47:175-180

72. Richards RI, Holman K, Friend K, Kremer E, Hillen D, Staples A, Brown WT, Goonewardena P, Tarleton J, Schwartz C, Sutherland GR 1992 Evidence of founder chromosomes in fragile X syndrome. Nat Genet 1:257-260

73. Oudet C, Mornet E, Serre JL, Thomas F, Lentes-Zengerling S, Kretz C, Deluchat C, Tejada I, Boue J, Boue A, Mandel JL 1993 Linkage disequilibrium between the fragile $\mathrm{X}$ mutation and two closely linked $\mathrm{CA}$ repeats suggests that fragile $\mathrm{X}$ chromosomes are derived from a small number of founder chromosomes. Am J Hum Genet 52:297-304

74. Hirst MC, Knight SJ, Christadoulou Z, Grewal PK, Fryns JP, Davies KE 1993 Origins of the fragile X syndrome mutation. J Med Genet 30:647-650

75. Oudet C, von Kuskull H, Nordstrom AM, Peippo M, Mandel JL 1993 Striking founder effect for the fragile X syndrome in Finland. Eur J Hum Genet 1:181-189

76. Buyle S, Reyniers E, Vits L, De Boulle K, Handig I, Wuyts FL, Deelen W, Halley DJ, Oostra BA, Willems PJ 1993 Founder effect in a Belgian-Dutch fragile X population. Hum Genet 92:269-272 
77. Macpherson JN, Bullman H, Youings SA, Jacobs PA 1994 Insert size and flanking haplotype in Fragile $\mathrm{X}$ and normal populations-possible multiple origins for the fragile X mutation. Hum Mol Genet 3:399-405

78. Holmgren G, Blomiquist K, Son H, Drugge U, Gustavson KH 1988 Fragile X families in a northern Swedish country. Am J Med Genet 30:673-679

79. Smits AP, Dreesen JC, Post JG, Smeets DF, de Die-Smulders C, Spaans-van der Bij T, Govaerts LC, Warren ST, Oostra BA, van Oost BA 1993 The fragile X syndrome: no evidence for any recent mutations. J Med Genet 30:94-96

80. Morton NE, Macpherson JN 1992 Population genetics of the fragile-X syndrome: multiallelic model for the FMR1 locus. Proc Natl Acad Sci USA 89:4215-4217

81. Chakravarti A 1992 Fragile X founder effect? Nat Genet 1:237-238

82. Kunst CB, Warren ST 1994 Cryptic and polar variation of the fragile X repeat could result in predisposing normal alleles. Cell 77:853-861

83. Hirst MC, Grewal PK, Davies KE 1994 Precursor arrays for triplet repeat expansion at the fragile X locus. Hum Mol Genet 3:1553-1560

84. Eichler EE, Holden J, Popovich BW, Reiss AL, Snow K, Thibodeau SN, Richards CS, Ward PA, Nelson DL 1994 Length of uninterrupted CGG repeats determines instability in the FMR1 gene. Nat Genet 8:88-94

85. Jeffreys AJ, Tamaki K, MacLeod A, Monkton DG, Neil DL, Armour JAL 1994 Complex gene conversion events in germline mutation at human minisatellites. Nat Genet 6:136-145

86. Richards RI, Sutherland GR 1994 Simple repeat DNA is not replicated simply. Nat Genet 6:114-116

87. Willems PJ, Van Roy B, De Boulle K, Vits L, Reyniers E, Beck O, Dumon JE, Verkerk A, Oostra B 1992 Segregation of the fragile X mutation from an affected male to his normal daughter. Hum Mol Genet 1:511-515

88. Reyniers E, Vits L, De Boulle K, Van Roy B, Van Velzen D, de Graaff E, Verkerk AJMH, Jorens HZ, Darby JK, Oostra BA, Willems PJ 1993 The full mutation in the FMR-1 gene of male fragile $X$ patients is absent in their sperm. Nat Genet 4:143-146

89. Bächner D, Manca A, Steinbach P, Wöhrle D, Just W, Vogel W, Hameister H, Poustka A 1993 Enhanced expression of the murine FMR1 gene during germ cel proliferation suggests a special function in both the male and the female gonad. Hum Mol Genet 2:2043-2050

90. Bächner D, Steinbach P, Wöhrle D, Just W, Vogel W, Hameister H, Manca A Poustka A 1993 Enhanced Fmr-1 expression in testis. Nat Genet 4:115-116

91. Bakker CE, Verheij C, Willemsen R, Vanderhelm R, Oerlemans F, Vermey M, Bygrave A, Hoogeveen AT, Oostra BA, Reyniers E, Deboulle K, Dhooge R, Cras P, Van Velzen D, Nagels G, Martin JJ, Dedeyn PP, Darby JK, Willems PJ 1994 Fmr1 knockout mice: a model to study fragile X mental retardation. Cell 78:23-33

92. De Graaff E, Rouillard P, Willems PJ, Smits APT, Rousseau F, Oostra BA 1995 Hotspot for deletions in the CGG repeat region of FMR1 in fragile X patients. Hum Mol Genet 4:45-49

93. Devys D, Biancalana V, Rousseau F, Boue J, Mandel JL, Oberle I 1992 Analysis of full fragile $\mathrm{X}$ mutations in fetal tissues and monozygotic twins indicate that abnormal methylation and somatic heterogeneity are established early in development. Am J Med Genet 43:208-216

94. Deelen W, Bakker C, Halley D, Oostra BA 1994 Conservation of CGG region in FMR1 gene in mammals. Am J Med Genet 51:513-516

95. Oberlé I, Rousseau F, Heitz D, Kretz C, Devys D, Hanauer A, Boue J, Bertheas MF, Mandel JL 1991 Instability of a 550-base pair DNA segment and abnormal methylation in fragile X syndrome. Science 252:1097-1102

96. Rousseau F, Heitz D, Biancalana V, Blumenfeld S, Kretz C, Boue J, Tommerup N, Van Der Hagen C, DeLozier-Blanchet C, Croquette MF, Gilgenkranz S, Jalbert P, Voelckel MA, Oberlé I, Mandel JL 1991 Direct diagnosis by DNA analysis of the fragile X syndrome of mental retardation. N Engl J Med 325:1673-1681

97. Sutherland GR, Gedeon A, Kornman L, Donnelly A, Byard RW, Mulley JC, Kremer E, Lynch M, Pritchard M, Yu S, Richards RI 1991 Prenatal diagnosis of fragile X syndrome by direct detection of the unstable DNA sequence. $\mathrm{N}$ Engl $\mathrm{J}$ Med 325:1720-1722

98. Verkerk AJ, de Vries BB, Niermeijer MF, Fu YH, Nelson DL, Warren ST, Majoor-Krakauer DF, Halley DJ, Oostra BA 1992 Intragenic probe used for diagnostics in fragile X families. Am J Med Genet 43:192-196
99. Oostra BA, Jacky PB, Brown WT, Rousseau F 1993 Guidelines for the diagnosis of fragile X syndrome. National Fragile X Foundation. J Med Genet 30:410 -413

100. Rousseau F, Robb LJ, Rouillard P, Derkaloustian VM 1994 No mental retardation in a man with $40 \%$ abnormal methylation at the FMR-1 locus and transmission of sperm cell mutations as premutations. Hum Mol Genet 3:927-930

101. Rousseau F, Heitz D, Tarleton J, Macpherson J, Malmgren H, Dahl N, Barnicoat A, Mathew C, Mornet E, Tejada I, Maddalena A, Spiegel R, Schinzel A, Marcos J, Schorderet DF, Schaap T, Maccioni L, Russo S, Jacobs PA, Schwartz C, Mandel JL 1994 A multicenter study on genotype-phenotype correlations in the fragile $\mathrm{X}$ syndrome, using direct diagnosis with probe StB 12.3: the first 2,253 cases. Am J Hum Genet 55:225-237

102. McConkie-Rosell A, Lachiewicz A, Spiridigliozzi GA, Tarleton J, Schoenwald S, Phelan MC, Goonewardena P, Ding X, Brown WT 1993 Evidence that methylation of the FMR1 locus is responsible for variant phenotypic expression of the fragile $\mathrm{X}$ syndrome. Am J Hum Genet 53:800-809

103. Hagerman RJ, Hull CE, Safanda JF, Carpenter I, Staley LW, Oconnor RA, Seydel C, Mazzocco M, Snow K, Thibodeau SN, Kuhl D, Nelson DL, Caskey CT, Taylor AK 1994 High functioning fragile X males: demonstration of an unmethylated fully expanded FMR-1 mutation associated with protein expression. Am J Med Genet 51:298-308

104. Von Koskull H, Gahmberg N, Salonen R, Salo A, Peippo M 1994 FRAXA locus in fragile $\mathrm{X}$ diagnosis: family studies, prenatal diagnosis, and diagnosis of sporadic cases of mental retardation. Am J Med Genet 51:486-489

105. Maddalena A, Hicks BD, Spence WC, Levinson G, Howardpeebles PN 1994 Prenatal diagnosis in known fragile X carriers. Am J Med Genet 51:490-496

106. Wang Q, Green E, Barnicoat A, Garrett D, Mullarkey M, Bobrow M, Mathew CG 1993 Cytogenetic versus DNA diagnosis in routine referrals for fragile X syndrome. Lancet 342:1025-1026

107. Van den Ouweland AMW, Devries BBA, Bakker PLG, Deelen WH, Degraaff E Vanhemel JO, Oostra BA, Niermeijer MF, Halley DJJ 1994 DNA diagnosis of the fragile $\mathrm{X}$ syndrome in a series of 236 mentally retarded subjects and evidence for a reversal of mutation in the FMR-1 gene. Am J Med Genet 51:482-485

108. De Vries LB, Halley DJ, Oostra BA, Niermeijer MF 1994 The fragile-X syndrome: a growing gene causing familial intellectual disability. J Intellect Disabil Res 38:1-8

109. Turner G, Robinson H, Laing S, Van den Berk M, Colley A, Goddard A, Sherman S, Partington M 1992 Population screening for fragile X syndrome. Lancet 339:1210-1213

110. Jacobs PA, Bullman H, Macpherson J, Youings S, Rooney V, Watson A, Dennis NR 1993 Population studies of the fragile X: a molecular approach. J Med Genet 30:454-459

111. Hagerman RJ, Wilson P, Staley LW, Lang KA, Fan T, Uhlhorn C, Jewellsmart S, Hull C, Drisko J, Flom K, Taylor AK 1994 Evaluation of school children at high risk for fragile $\mathrm{X}$ syndrome utilizing buccal cell FMR-1 testing. Am J Med Genet 51:474-481

112. Palomaki GE, Haddow JE 1993 Is it time for population-based prenatal screening for fragile X? Lancet 341:373-374

113. Snow K, Doud LK, Hagerman R, Pergolizzi RG, Erster SH, Thibodeau SN 1993 Analysis of a CGG sequence at the FMR-1 locus in fragile $X$ families and in the general population. Am J Hum Genet 53:1217-1228

114. Reiss AL, Kazazian HH, Krebs CM, Mcaughan A, Boehm CD, Abrams MT, Nelson DL 1994 Frequency and stability of the fragile X premutation. Hum Mol Genet 3:393-398

115. Young ID 1993 Diagnosing fragile $X$ syndrome. Lancet 342:1004-1005

116. Bradley DM, Parsons EP, Clarke AJ 1993 Experience with screening newborns for Duchenne muscular dystrophy in Wales. BMJ 306:357-360

117. Willemsen R, Mohkamsing S, De Vries B, Devys D, Van den Ouweland A, Mandel JL, Galjaard H, Oostra B 1995 Rapid antibody test for fragile X syndrome. Lancet 345:1147-1148 